\title{
Estética del humor en la novela de Carlos Carrión Figueroa
}

\author{
Ruth Rodríguez Serrano \\ Universidad San Francisco de Quito \\ rrodriguez@usfq.edu.ec
}

Recibido: 6-junio - 2018 / Aceptado: 30 - agosto - 2018

\section{Resumen}

El humor es una peculiar forma de enfrentar los problemas y explicar los comportamientos de muchos ecuatorianos que han tenido que migrar en las últimas décadas. Este artículo analiza el ingrediente del humor en tres obras de Carlos Carrión que son claves para entender, desde el punto de vista antropológico, el fenómeno de la migración y sus consecuencias a nivel individual y social. Otro aspecto que contribuye a esclarecer el ingrediente del humor como instrumento de expresión del efecto migratorio en la obra de Carrión, es la estética, que en el arte literario del escritor adquiere su súmmum en el manejo de lo erótico, donde el cuerpo se convierte en representación clara de una singular identidad.

Palabras clave: humor, estética del humor, fenómeno migratorio, novela ecuatoriana, novela erótica, identidad cultural.

\section{Abstract}

Humor is a peculiar way to face problems and explain the behaviors of many Ecuadorians who had to migrate in recent decades. This article discusses the ingredient of humor in three novels by Carlos Carrión that are key to understand, from the anthropological point of view, the phenomenon of migration and its consequences at individual and social levels. Another 
aspect that helps clarify the ingredient of humour as a means of expression of the immigration effect in the work of Carrion, is the esthetic, which acquires its summum in the management of the erotic, where the body becomes in the literary art of the writer in clear representation of a singular identity.

Keywords: humor, esthetic of the humor, immigration, Ecuadorian novel, erotic novel, cultural identity. 
$\mathrm{D}$ esde la Poética de Aristóteles, el humor en la literatura ha estado vinculado al subgénero dramático de la comedia donde el personaje se caracteriza por su condición risible, su errabundo destino de deshonor, alejado de la ciudad en calidad de ser inferior, defectuoso o patético, cuyas expresiones y acciones carentes de lógica resultan inadecuadas y, por lo tanto, cómicas. El deleite producido en el lector es en estos casos una forma de persuasión por lo subliminal, cuya finalidad última sería la conciliación de pensamientos opuestos. En todo el proceso que supone este pacto armónico con lo ingenioso, la existencia de una censura interna que englobe entendimientos sobre un espacio y un tiempo determinados, que según sean valorados por estéticas serias como el patetismo y el didactismo, o por comprensiones más informales como el arte del humorismo, otorga un puesto diferente a cada obra dentro de la cultura donde se enmarca. De este modo, el humor como objeto estético muchas veces es desestimado por la cultura oficial y llevado a un plano de mera diversión.

En América Latina cuya organización social está basada en la desigualdad, la risa pasa desde las altas esferas del humor crítico al humor puramente hedonista. Las estéticas derivadas de las diferentes visiones hacen necesario, según Beltrán Almería, (cit in Karageorgou \& Mungía, 2003, p. 158) "replantear de raíz la historia de la cultura occidental que ha dejado en la oscuridad todo un continente perceptivo y valorativo de la vida". Para este autor, la risa tiene la capacidad de borrar fronteras y ser una fuerza crítica de la desigualdad. Tomando en cuenta esta visión sobre las contribuciones ignoradas del humor dentro de la literatura, la presente ponencia intenta rescatar las aportaciones de índole antropológica que se encuentran en tres novelas del autor Carlos Carrión Figueroa, las mismas que se circunscriben al tema de la migración de ecuatorianos a España, sus vicisitudes, angustias, cambios, descubrimientos y demás vivencias que hacen posible conocer la dinámica de la relación entre culturas, los efectos sociales, psicológicos y de identidad que se traslucen a través de historias testimoniales contadas con un humor capaz de destruir las viejas concepciones que sobre lo moral se plantea la modernidad, y de presentar una nueva visión de la comicidad con capacidad crítica, inmoderada e irreverente que expone realidades irónicas, que por su veracidad dejan atrás la estética García-marciana de lo mágico, para acercarse a otra a la que tal vez podríamos inscribirla dentro del realismo caricaturesco, por su aproximación a la sombra que revela el carácter deformante del sistema social y político del cual emerge como efecto existencial.

En sus novelas, Carrión ensaya la comedia dramática como principio constructivo. Lo sentimental confiere fuerza y unidad al tema, que ya de por sí reviste dolor; pero este no es motivo para crear una tragicomedia, sino que logra mover su resiliencia para catapultarse hacia lo amargo del humor, tanto que a veces el lector no atina, igual que el personaje, a reír o llorar sobre su humana condición. En muchos casos, el humor funciona como comunicación persuasiva que estropea la seriedad y crueldad de los acontecimientos, como si la misma vida no fuera más que un objeto 
efímero que ha llegado como juguete entre las manos. Pero, ¿es que acaso, la realidad de la migración no nos pone de narices frente a sucesos que, de no ser llevados con humor, marcarían nuestra memoria con consuelos superficiales?

La diáspora en Ecuador comienza por los años 60 del siglo anterior y se dirige a 55 países del orbe. La región sur del país es la que más se sacude con este triste modo de supervivencia, sus habitantes escogen como destino preferido países de lenguas familiares como España e Italia. A partir de 1988 la migración empieza a crecer y alcanza su mayor auge con la crisis de 1999, y como resultado se aprecian fenómenos multiclasistas, multigeneracionales y se feminiza (Herrera, Carrillo \& Torres, 2005, p. 14). Es en el Ecuador de mitad del siglo XX y comienzos del siglo XXI donde se sitúa el escenario de las tres novelas de Carrión que en conjunto pertenecen a la colección "La seducción de los sudacas", y que se analizan a continuación.

Carlos Carrión nace en Loja en el año 1944. Ha publicado un sinnúmero de novelas, algunas de ellas han sido merecedoras de premios nacionales como el José de la Cuadra, el premio Joaquín Gallegos Lara, el premio Pablo Palacio, el premio Miguel Riofrío, e internacionales como el Latin Hermitage Foundation, y la presea Isabel la Católica. Además, ha sido el finalista del Premio Herralde en 2004. El presente ensayo constituye un estudio de tres obras que pertenecen a un conjunto de novelas que se encuentran dentro de una mayor, titulada "La seducción de los sudacas", y que pertenece al género testimonial, pues reúne relatos de muchos migrantes que colaboraron con el autor en la narración de sus vivencias reales.

La primera novela se titula La utopía de Madrid. Narra la historia de Lucy, una joven madre lojana que migra a España en busca de mejores condiciones de vida. Como muchos de los personajes de estas historias, esta mujer pasa por grandes vicisitudes que van desde la humillación por parte de sus patronos, experiencias en trabajos denigrantes, desmembración familiar, olvido de las raíces, aculturación. La novela utiliza un humor inocente que revela con agria ironía el dramatismo de la vida de Lucy, sus encuentros, comprensiones y su participación en un final inesperado lleno de gracia, al conquistar un duque que es la personificación de la rancia sobriedad española.

Con lo primero que se enfrenta el lector de esta novela es la oposición de dos identidades totalmente diversas. El comportamiento de los "sudacas" pertenecientes a una sociedad colectivista, mal venidos a una nación de talante individualista. La integración social con el otro diferente devela el planteamiento que los personajes se hacen sobre las causas de su nueva condición. Todos los personajes en su mayoría son jóvenes que creyeron en la utopía de cumplir expectativas laborales y económicas que, una vez aterrizadas en la nueva realidad, no llegan a concretarse de la manera soñada. Nos vemos frente a una narración de procesos, desde el momento en que el migrante decide abandonar su patria hasta el momento de la desilusión. El imaginario de quienes migraron antes de la crisis económica del Ecuador de la última década del siglo anterior, se instala a modo de esperanza a través de llamadas 
hacia amigos que pretenden migrar. Se cuenta una realidad deformada acerca de la posibilidad rápida de encontrar empleo con una buena remuneración, cuando la verdad es que el migrante tiene que vérselas muy duro para conseguirlo. En La utopía de Madrid observamos el caso de Rudy, quien a través de conversaciones telefónicas convence a Lucy de migrar hacia la capital española. Luego de un largo viacrucis en búsqueda de trabajo, la joven comenta tristemente:

Voy a probar con los porteros automáticos, me convenzo desolada. Del frío me duelen las orejas, la nariz y los dedos. Odio a Rudy y estoy hambrienta. Pienso que los porteros son una cosa más fácil de tolerar o al menos no te permite ver las caras que te dicen no. Pulso los botones y espero con ansia. Me parece esperar un montón de tiempo para contestarme, pero, cuando al fin lo hacen, son voces tan agrias que, apenas empezar yo el rollo que llevo preparado, ellas joder, estoy hasta los cojones de inmigrantes puñeteros, de tontos lavas, de sudacas gilipollas. Me dejan temblando (Carrión, 2013, p. 20).

Representado en el cuerpo de Lucy, este personaje común que ve poco a poco como sus sueños se desvanecen, evidencia que los jóvenes ecuatorianos tomaron la decisión de migrar movidos por la difícil situación económica, y las falsas expectativas creadas por los medios de comunicación alrededor de lo que ofrecía España.

Pero la narración de los tormentos del migrante no se queda ahí, el contraste entre los valores que se da a la familia del país de origen en comparación a como el núcleo familiar es considerado en Espańa, parece ser otro elemento que produce desasosiego y angustia en el ecuatoriano, quien al migrar por amor al hijo, no quiere comprender que al otro lado del mundo este sea un valor irrelevante. Y que además no deja de ser una broma pesada del destino que los lazos que se pretendió construir a través de cumplir con la responsabilidad materna, se difuminen con el paso del tiempo y la distancia. Esto lo cuenta Lucy cuando narra la experiencia de una madre que casi nunca recibe la visita de su hija:

Apenas amanece vuelve el tema del desamor de la hija. María Luisa no me quiere, dice y llora, jamás, Lucy. Que te lo digo yo. Ya la tiene abandonada como huérfana de padre y madre, joder. Escucho sus sollozos y lloro también porque yo soy igualmente huérfana de mi hijo. Lo llamo y nunca está y cuando está, nomás: hola mami y envíame tanto, con la excusa del cole y los amigos (Carrión, 2013, p. 46).

El temor, entonces, se vuelve constatación de estar en un tiempo y en un espacio equivocados; de saber que no se puede contar ni sentirse respaldado con los mismos criterios de comunidad de la tierra de la cual se partió.

No más profunda es la amargura de sentirse un total desconocido para el otro, que la desvalorización venga del poco conocimiento que se tiene de Ecuador por parte de un español: 
La primera vez del hilo blanco fue la monda. Oí mal y volé al costurero, cojo un ovillo de hilo blanco y se lo doy, tan pancha. Me lo lanzó a la cabeza; te dije vino blanco, no hilo blanco. ¿No sabes lo que es eso? Y se explayó en burlas de que, claro, cómo ibas a saber que se cocinaba con vino blanco si venías de Ecuador, que estaba en plena África, ¿no?, y ya era bastante ciencia que no fueras negra morruda y hablaras, español, hablaras (Carrión, 2013, p. 29).

Como se ve en la novela, el choque cultural es muy fuerte, lo cual trae una transformación rápida y contundente del migrante joven, quien se ve tentado a regresar a su país, con la consiguiente sensación de derrota y vergüenza por no haber triunfado en una tierra que parecía prometida. Gran cantidad de variables contribuyen a la desidealización del sueńo, pero a la vez, al condicionamiento del deseo migratorio porque mientras exista la posibilidad de ganarse la lotería de un buen empleo o la posibilidad de que la buena suerte sea la recompensa supersticiosa de quien aún espera el beneficio del Cielo, la integración estará psicológicamente instalada como utopía. En la novela, pues, se retrata esta utopía con el caso de Lucy, quien, como en cuento mágico, termina conquistando a un duque de verdad.

No obstante, el duro escenario en que se desenvuelven los personajes de esta primera novela, el humor juega un papel balsámico con el cual se pretende una dulce venganza en la concepción del ecuatoriano, que juzga como absurdo el comportamiento del país anfitrión. En un pasaje, Lucy afirma: "Estoy planchando correteada por los gritos y por un momento imagino que la señora es feliz gritando. Como profesional del grito. Como Montserrat Caballé o María Callas, dice Rudy, que sabe de locas de remate" (Carrión, 2013, p. 54). Desde la teoría psicoanalítica, el humor nos sirve para descargar la tensión excesiva, no es de extrañar que en momentos de gran stress, los personajes recurran a la broma para huir de aquello que consideran tortuoso, y tiendan a ridiculizarlo como cuando Lucy termina diciendo:

Deberían ir a un psicólogo; pero no, a gritar, a insultar es a lo que van. Desde que amanece hasta que anochece. Y a cargarse en todo, madre mía. En la madre que te parió, en la leche, en la mar, en la virgen, en la hostia. Porque los espańoles sin dejar uno sufren una irreverente diarrea crónica (...) Y mandan a la puta calle, te mandan. A tu puto país (Carrión, 2013, p. 96).

Aquí la broma, pasa de ser un mecanismo de defensa a ser una forma de enfatizar que los implicados pertenecen a grupos diferentes, de los cuales quien obtendría mayor seguridad psicológica sería la migrante que se mofa. Por lo tanto, la estética con la cual el humor de Carrión se reviste responde a una disociación entre dos marcos de referencia que son incompatibles, pues responden a esquemas de comportamiento diferentes.

En el juego humorístico de Carrión también intervienen elementos cognitivos y emocionales que proveen al lector de una dimensión social sobre el contexto cultural e histórico de donde proviene el personaje del migrante. Se establece así una caricatura sobre las opiniones que los protagonistas tienen sobre temas políticos, 
que mezclados con situaciones ordinarias de la vida terminan por aclarar la mentalidad del grupo del bromista. El escritor usa la ironía para criticar, por ejemplo, el antiguo pleito territorial que por años ha quedado en la memoria del lojano con respecto a las disputas con el Perú: "Estoy tan alicaída que ni las folladas de Joaquín me alientan mucho, como si acostarme con un peruano fuera traición a la patria" (Carrión, 2013, p. 74), dice Lucy cuyo novio procede de ese país. Pero la ironía va más allá, cuando las fronteras y viejas rencillas de guerra parecen borrarse en cuanto los personajes reconocen que a pesar de ser enemigos virtuales en la memoria, logran apoyarse en tierra extraña por ser parte de una historia común aún más antigua, que los identifica como víctimas de lo que quizá, aún en la actualidad, no logra perdonarse en tierras conquistadas. En un episodio de la novela, Betty, la amiga peruana que convive con Lucy se encuentra unas joyas en el dormitorio de la duquesa y dice:

Son joyas provenientes del Perú, Lucy. Cuando los españoles gilipollas eran los dueños y señores de América y Pizarro le pidió a Atahualpa el rescate de la puta madre que le pidió, ¿no te acuerdas? Y después los demás ladrones en los siglos de siglos de la colonia (Carrión, 2013, p. 144).

Luego Lucy contesta: “¿Cómo sabes que es peruano? Podría ser de México, de Colombia, de Ecuador; por todos esos lados estuvieron ellos hartándose de oro" (Carrión, 2013, p. 144). Y luego Betty argumenta: "al olor, Lucy, ¿no te enteras? Estas joyas me huelen al Perú... (Carrión, 2013, p. 144). Pero al día siguiente Lucy las huele y comenta que solo le huelen a joyas guardadas y frías. "Pero no, la chalada de Betty, al Perú, al Perú. Ni que fueran pachamanca, seco de chavelo o papa a la huancaína. Le digo, además, Atahualpa fue quiteño y se cargó a Huáscar. Entonces se cabrea y cambia de conversación” (Carrión, 2013, p. 144). Sin duda, esta bipolaridad conceptual sobre lo que se debe odiar en un momento y amar en otro, es tema perfecto para retratar sarcásticamente lo que se considera aceptable o no dentro del grupo de migrantes que se ven impelidos a olvidar y recordar según convenga reforzar lazos sociales. Por eso aquí el humor de Carrión deja al descubierto el ridículo de una identificación con algo que al final no existe.

Otro punto que no puede pasarse por alto al momento de analizar Utopía de Madrid es el lenguaje ligado sutilmente al dolor como forma de querer conciliar lo irreconciliable de las dos culturas. Mientras por un lado se presenta lo español como la espada cortante, directa, rápida, muchas veces cruel, se dibuja lo latino como el escudo defensor de una historia difícil de olvidar, que enfatiza en el verbo, en la reiteración de la palabra dentro de la frase, como una forma de recordar el significado más allá de lo meramente literal, para centrarse en el sentido ontológico del vocablo transmisor de sentimiento. Aquí un ejemplo de lo que para el migrante latino resulta doloroso de la forma de hablar española: 
Lo saludo y le digo si no quiere una chica para el trabajo que sea. Joder, dice, y ¿si quiero una para que me rasque los cojones? Suelta una carcajada de asno capaz de derribar las sillas que los otros imitan. Y adivino el significado de esa palabra que Rudy me ha dicho tantas veces en el teléfono, y me quedo mirando a uno y a otro con una mezcla de asombro y coraje... (Carrión, 2013, p. 20).

Y he aquí el patrón de la figura literaria de la anáfora del dialecto lojano, en algunas partes de la novela: "Y no me queda más que obedecerle, no me queda (Carrión, 2013, p. 99). "Don Javier no abre el pico para nada; pero algo es algo, ¿no? Del lobo un pelo, como quien dice, del lobo" (Carrión, 2013, p. 124). "Llego con las justas y, con el niño de la mano, empiezo a andar. Es chévere estar con él por estas calles ajenas y frías, verlo sonreír, mirar los escaparates, mirar" (Carrión, 2013, p. 91).

Porque aquí en Martínez Campos, 18, me zampo almuerzos de reina; pero, claro, nadie viene a Espańa por comer de caridad aunque coma maravillas. Y me dan ganas de llorar y lloro. Sin que me insulte nadie, no te jode. Solo porque esta vida no es vida, solo" (Carrión, 2013, p. 109).

Y esta última entre tantas: "Y lo peor es que no sé cuándo terminará esta joda, no sé cuándo" (Carrión, 2013, p. 101). La anáfora tiene aquí la función de remarcar lo absurdo de la vivencia y, a través de ello, retratar sarcásticamente las odiseas interiores del migrante.

El tratamiento descriptivo del lenguaje en Utopía de Madrid es clave para entender cómo se va dando el proceso de absorción de una nueva cultura, cómo el migrante va olvidando de a poco su identidad a través de la adopción de formas de expresión de las que en un primer momento renegaba. De esta manera, Lucy nos cuenta: "Yo me quedo sin respiro pensando, madre mía, no lo he cortado por la línea de puntos que es de cortar, al tiempo que la mando a la mierda con el pensamiento, porque ya estoy de ella hasta los cojones" (Carrión, 2013, p. 32). Por último, no menos conmovedor resulta el hecho de constatar a través del uso del lenguaje, que el sueño oculto de regresar a la aldea en la que un día se gozó de relativa dignidad, está aún latente como una estrella escondida tras las nubes del destierro: "Miro los edificios enormes, los toldos verdes y tomate en las ventanas y la gente extrańa y su habla tan extraña como ella" (Carrión, 2013, p. 21). Todas estas son frases que denotan historias de desarraigo que recrean una búsqueda de sentido y pertenencia a una historia de vida que el migrante nunca esperó. En sí, son la constatación de la utopía a la que hace referencia el título de la obra.

La segunda novela a la que quiero hacer mención es La mantis religiosa, que ha sido denominada por Jorge Dávila Vázquez como "la novela más erótica del Ecuador". Su argumento no puede ser más atractivo: la historia de Loli, una joven de exuberante belleza que emigra a España en búsqueda de trabajo. Con un título de 
licenciada en literatura bajo el brazo, nada puede alcanzar en la desdeńosa capital madrileńa que solo busca migrantes ecuatorianas para cubrir puestos de empleadas domésticas, cuidadoras de ancianos decrépitos o niños olvidados por padres pendientes del mundo del trabajo. Loli tiene suerte: un buen día ve un anuncio de prensa que le salva el pellejo: "Matrimonio de 60-56 años, bien física y económicamente, busca chica entre 20-25 guapa, culta y apasionada para relaciones con él”. Desde entonces, la vida de Loli se convierte en una vorágine de extrañas y apasionantes experiencias vinculadas al placer, al arte de ser un personaje de carne y hueso en la vida de un escritor, y al inquietante descubrimiento de una cultura llena de detalles y vivencias desde todo punto exóticas para una muchacha venida de un pequeño pueblo de Loja.

El erotismo de La mantis religiosa tiene expresión en el cuerpo del hombre y la mujer, sin jamás relegarlos a meros objetos sexuales. Antes bien, es a través del cuerpo como se logra abstraer un sinnúmero de comprensiones relacionadas con el desarraigo, la búsqueda de la nueva identidad, el locus del dolor que se sublimiza en el punto máximo de placer carnal. La novela de Carrión muestra, por otro lado, el cambio de mentalidad femenina más abierta a la exploración del cuerpo como forma de autoconocimiento. La mujer hace su historia a través de un lenguaje corporal propio donde aparecen nuevas construcciones simbólicas sobre la búsqueda de libertad dentro de un escenario duramente represivo como lo es el de la infravaloración cultural.

En esta novela de Carrión aparecen verdaderas joyas eróticas que convierten al cuerpo en la puerta de escape hacia el único placer encontrado dentro del humillante juego por la sobrevivencia:

Supo, de repente, que había omitido el momento más perfecto del día soñado: el del baño. Antonio pondría la tina y, cuando estuviera medio llena y con las sales de baño que a ella le encantaban, la llevaría allí en brazos. Antes de sumergirla en el agua, la enjabonaría poniéndola en cuatro patas, como una yegua de mar. Loli cerraría los ojos y suspiraría para que la mano del jabón empezara en su nuca y concluyera en sus nalgas, demorada, sutil y profunda (Carrión, 2014, p. 162).

De esta forma, la búsqueda del placer es la búsqueda del sentido a la sinrazón de ofrecer el cuerpo como método de subsistencia; pero al mismo tiempo, es una noción bienvenida al momento de analizar la presente novela como unidad sistémica que, al reflejar las relaciones entre la mujer, los cuerpos y la historia del desencanto migratorio, permitirá abstraer las consideraciones que sobre el ser femenino se han vertido en esta historia de migrantes.

El humor es creación estética a través de la complicidad entre lo obsceno y la sexualidad. Con cuidadas formas expresivas se logra una precisa descripción del deseo carnal y a la vez se establece críticas y episodios jocosos con respecto a la institucionalidad e informalidad, realidades contradictorias de las cuales el escritor ironiza: 
Ganó centímetro a centímetro el país de seda de la chica, su anhelada trinchera de soldado. Por fin, hundió en la vulva su boca quemada por el sol del desierto y lamió su sal fresca. Lo hizo con ansiedad lenta y repetida, con erudición de académico de la lengua, buscando los bordes del placer, la yema de la desesperación de Loli, de modo que ella pensó que se iba a morir en la boca de Antonio, no como una mujer, sino como una fruta, y que no recibiría, lastimita, la paga de su primera noche de trabajo (Carrión, 2014, p. 49).

Humor y erotismo es otra de las combinaciones geniales de esta obra, un desafío que muy pocos pueden proponerse para lograr un desenlace irónico que refleje, a través de la utilización de imágenes, un summum de la tragicomedia del exilio.

El cuerpo masculino es exaltado a través de descripciones que denotan su posibilidad de conquista, la misma que además parece connotar cierta relación entre el conquistador de las indias y el Nuevo Mundo. Este último erigido sobre el cuerpo de Loli que, irónicamente, se convierte en el espacio de libertad del escritor espańol, protagonista principal de la novela. Los cuerpos son sorprendidos, mirados y deseados por el lector que se ve impelido a seguir el hilo del desenlace amoroso. A esta deleitada experiencia, le agrega el autor el condimento del humor con el fin de criticar la represión del ambiente social y cultural del cual forma parte, y del cual solo Loli posee la llave salvaje de la liberación:

Se dijo, sea lo que Dios quiera y se apegó a la carne cautiva, a su fragancia, la beso en la frente, la lamió un minuto, dos, tres, y, por fin, la engulló con sabiduría no aprendida. Entre tanto el escritor, como una mantis religiosa macho, tuvo el súbito deseo de ser masticado y comido vivo por los dientes y la boca de la chica: sin anestesia ninguna, sin curas al lado para una confesión ni notario para un testamento. Nada más que eso: ser comido. Como único anhelo de hombre. Porque así se libraría para siempre del amado horror de escribir una novela más, del anhelo del Premio Planeta, de José Manuel Lara, de todo (Carrión, 2014, p. 51).

El manejo de la ironía está también presente en variadas situaciones donde se tiende a comparar las valoraciones que sobre cultura e imagen se establecen entre Espańa y Ecuador. Las contradicciones aparecen como condiciones naturales que crean fricción para al final dar con la triste constatación de seres divididos entre su necesidad de sobrevivir y su ilusión de permitirse ser lo que siempre anhelaron. Así pues, se relata la situación de muchos migrantes que, habiendo obtenido un título universitario en Ecuador, llegan a España con conocimientos que delatan las brechas culturales y generan subestimación de los valores del migrante:

¿Qué estudiaste?, le dijo Antonio, tal vez con inquietud (...). Literatura. ¿Literatura?, susurraron los dos con asombro. Loli los vio levantar las cejas y siguió hablando dichosa. Sí, le encantaban los libros. Magarita Duras, Neruda, García Lorca, César Dávila Andrade, Carlos Eduardo Jaramillo. A ellos, ¿no? (...) Antonio y Bibi estuvieron a punto de reír. El hombre incluso bien pudo decirle que no. No leía a esos autores (Carrión, 2014, p. 30). 
No obstante, más adelante, Carrión relativiza este hecho, riéndose de sí mismo como parte del conjunto de autores invalidados por la crítica de la "Madre Patria" a la que muchos escritores noveles se ven obligados a acudir para publicar. Quien no publica primero allá, por lo general es denostado como profeta en su propia tierra. Pero para Carrión, la historia simplemente puede ser otra: las novelas latinoamericanas sí tienen un público fiel, y es justamente aquel lector que no necesita ser medido con la vara de otra de cultura para sentir que lo que lee forma parte la aprehensión estética del mundo al que pertenece y extrańa hacerlo suyo por derecho:

De pronto o después de mucho tiempo sintió que estaba acostada. Suspiró sin desear otra cosa que dormir hasta mañana y que Antonio le leyera "Los venenos" de Cortázar, "Ana María" de Donoso, "Una niña adorada" de Carrión, sus relatos preferidos. Percibió un dulzor, recorriéndola. Y, junto con el dulzor, un estremecimiento" (Carrión, 2014, p. 48).

No es menos cierto que este estremecimiento del cual habla Carrión y que acompaña a Loli hasta el final de la novela, es en realidad una profunda nostalgia por todo lo que comprende el cuerpo simbólico de la patria lejana, incluido el mismo sentido del humor plasmado en obras que han sido subestimadas por la crítica extranjera.

El humor ácido de Carrión se convierte en el termómetro que mide la temperatura de los efectos sociales, psicológicos y emocionales de la población de migrantes. Dado que una buena parte de esta población son mujeres, las historias nos revelan verdaderos dramas de su desaliento, abandono, separación, olvido de los propios sueños y valores que un día constituyeron el motor por el cual decidirse a emigrar: el amor por la familia, la procura de un futuro mejor para los hijos, el crecimiento personal, el triunfo basado en el esfuerzo. Todas estas motivaciones quedan en el costado más amargo del éxito: buenas remesas, sí, pero que sostienen a familias desmembradas, pérdida, subestimación y olvido de los valores nacionales, morales, que hacen que mujeres como Loli se replanteen su sentido de ser al estar en un mundo que jamás quisieron ni imaginaron al emigrar:

La ausencia del placer la llevó al recuerdo, quizá a la angustia. Antes limpiaba pisos, traseros, cuidaba ancianos, tontos salidos, locas, planchaba. Ahora vendía orgasmos. ¿Era eso tocar fondo en su vida de mujer? ¿Estar en la última abyección? ¿O una mejora? Porque, si vendía orgasmos, no era sino una puta. Pero claro, no estaba en la calle Montera como las rumanas. Estaba en la cama de un escritor" (Carrión, 2014, p. 95).

No obstante, el drama que desata la historia de Loli, la novela se inserta en la evolución de la feminidad en la que la mujer hace su historia en el reconocimiento del placer a través de su cuerpo, desde el cual ejerce su derecho a la protesta hacia una historia política que atropella su dignidad.

La tercera obra, Quién me ayuda a matar a mi mujer, es quizá, una de las novelas más ingeniosas de Carrión; tiene como escenarios Madrid y Ecuador, lo cual per- 
mite un análisis contrastante de ambas culturas y a la vez constituye un viraje de mirada hacia la idiosincrasia ecuatoriana, desde los ojos de uno de los principales personajes, María Rosa, una española que cae en la mala fortuna de enamorarse de un músico lojano, que por desgracia se dedica a la bohemia. Sus ingredientes son los mismos: testimonio migratorio en los tiempos postreros a Franco, amor, erotismo, humor corrosivo, final dramático que hará partirse de risa al lector. Su argumento empieza con el viaje de un hombre joven a España, con la finalidad de estudiar música. Allí conoce a una hermosa mujer a quien no ama realmente, pero que se ve obligado a casarse debido a la mentira de un embarazo, embuste que costará caro a la protagonista, a quien su esposo, eternamente enamorado de una relación de juventud, tratará de eliminar de varias formas inventando trampas disparatadas, sin llegar a cumplir su objetivo.

La novela se desarrolla en la época posfranquista, por lo cual los personajes siguen respondiendo a una sociedad tradicional, donde derechos de hombres y mujeres son asimétricos, relegándose a estas últimas al papel de madres; de ahí se entiende el comportamiento de María Rosa que, para evitar quedarse solterona recurre a la mentira de un embarazo. "Era una época de morales grandes y perfectas y después de cobrarme, el administrador me dijo que no recibía parejas que no estuvieran casadas y con el libro de familia en la mano" (Carrión, 2014, p. 35). Ulpiano, el joven lojano que migra con el fin de estudiar música, no resiente estos valores, pues proviene de una sociedad pueblerina y cerrada donde no es de extrañar cierta obediencia al patriarcado, por ello es que acepta las condiciones del destino y decide casarse con María Rosa, aun en contra de sus sentimientos fieles hacia su novia de Juventud, Johana.

El migrante de esta época no se las ve fáciles con respecto a los problemas de xenofobia que permanecen como rezagos del franquismo. Ello se ve ejemplificado en la novela, cuando un soldado golpea a Ulpiano por el simple hecho de estar tocando su violín en la vía pública: "Joder con este indio: ¿qué estás haciendo aquí hecho el ángel de la noche, eh? -me dijo un sargento, quitándome el saxo con violencia" (Carrión, 2015, p.78). Los años sesenta a ochenta son años de crisis y cambios hacia la transición de la democracia en Espańa. Es por esta época que este país comienza a recibir inmigrantes que se transforman en un activo económico que obliga a adaptar el marco jurídico y la acción política con respecto al inmigrante como sujeto de derechos, por lo que "aflora el sentimiento racista y xenófobo como consecuencia del desarrollo de este fenómeno y las implicaciones culturales que deja como legado" (Blasco, 2015, p. 13).

El lojano, por el lado de su historia, comienza a migrar justamente a comienzos de los años setenta como efecto de una devastadora sequía, primero a otros lugares del país donde forman nuevos centros urbanos como Nueva Loja en Sucumbíos, San Vicente de Loja en Guayas, Santo Domingo de los Colorados, y numerosas colonias en Zamora Chinchipe Chinchipe (Moncada, 2003, cit in Alarcón, Ordóñez, Torres y Contreras, 2010, p. 13). Según estos mismos autores: 
La importancia de la migración de los lojanos hacia España se refleja en la cantidad de compatriotas que se encuentran en ese país. En este sentido, según Colectivo IOE (2001), de Loja proviene un $16 \%$ del total de ecuatorianos residentes en España, haciendo de esta provincia, la segunda en importancia después de Pichincha, que habría enviado fuera del país a más del $30 \%$ de los ecuatorianos.

Como puede verse, no es de extrañar que varios autores ecuatorianos hayan tomado el tema de la migración desde hace mucho, dado que si queremos de algún modo entender nuestro problema de identidad, debemos entender las razones por las cuales hemos estado siempre en continuo flujo migratorio. Así, sería de considerar el tema al menos desde inicios del siglo XX con A la Costa (1904) de Luis Alfredo Martínez, y pasar luego por otras novelas emblemáticas como El éxodo de Yangana (1949) de Angel Felicísimo Rojas, Los hijos (1962) de Alfredo Cuesta y Cuesta, El muelle (1933) de Alfredo Pareja Diezcanseco, La Dama es una trampa (1989) de Galo Galarza, Camas Calientes (2005) de Jorge Becerra, El inmigrante (2004) de Gonzalo Merino, para llegar a un conjunto de novelas que se encuentran bajo el título La seducción de los sudacas de Carlos Carrión, que comprende, además de las obras estudiadas aquí, otras que se encuentran en estado inédito como son La vedet de la calle Valverde, El tren de los amantes, Un bacán en Nueva York y Pájaros de alto vuelo, que sin duda serán un referente clave de la historia literaria del Ecuador y merecerán un estudio por parte de la crítica, una vez que tengamos la suerte de verlas publicadas.

La estética humorística en ¿Quién me ayuda a matar a mi mujer” va armándose conforme el argumento se desarrolla. Son los episodios, que a manera de piezas de un rompecabezas van dibujando el entramado con altísimo suspenso, dejando que el lector se sorprenda con las magistrales descripciones del absurdo. El disfrute de la novela está en el conocimiento que mueve las oscuras intenciones de la pareja de Ulpiano y María Rosa, por lo que la imprescindible descripción del mundo interior de los personajes resulta un trabajo bien hecho, al lograr mostrar con nitidez el proceso de cambio que sufre la psicología de ambos miembros del matrimonio. Movidos por las circunstancias, los esposos caen víctimas de sus propias pasiones: él por la música, ella por un amor asfixiante hacia Ulpiano. En la narración de los sucesos, Carrión logra satirizar el encuentro entre la ingenuidad provinciana de un hombre y el oportunismo de una mujer española, como una crítica a la memoria que sobre la conquista aún permanece en territorios sudamericanos.

Este desnivel también se encuentra reflejado en el comportamiento del ciudadano español con respecto al latino, con un lenguaje humorístico que otorga frescura al estilo del texto:

María Rosa estaba recién sentada sobre mis piernas en el puesto del copiloto y yo que, como ya dije, a pesar de mis 25 ańos, no había conocido hasta entonces una mujer en sentido bíblico, tanto por no tener una biblia como tampoco una mujer, solo rezaba, sufría y temblaba, 
sin saber cómo ni cuándo ni por dónde; en especial por no tener que pasar por la vergüenza de tener que preguntárselo a María Rosa (Carrión, 2014, p. 40).

El humor logra permear todos los lados de la novela con pequeńas y repetidas pinceladas de gracia que se introducen inclusive en la descripción de actos eróticos:

No satisfecha con una agonía, ella buscó agonizar cuatro veces más; de modo que la odié como nunca, porque cuando creí que terminaba de ser caballo de carrera para volver a ser hombre, tuve que ser burro de carga y empezar de nuevo. Por fin se derrumbó sobre mí, temblando y empapada en sudor (Carrión, 2014, p. 77).

Humor y erotismo, tienen también aquí un encuentro de radiantes resultados. Para Hernán Rodríguez Castelo, Carrión es el escritor que mejor maneja, con libertad, humanidad y sensualidad el tema erótico (cit in León, 2014, p.15).

Sólo con el ánimo de bosquejar el espíritu humorístico de la novela, y dejar al lector con la inquietud y deseo de leerla, se cuenta aquí sucintamente su argumento:

Vemos en el escenario de Madrid, en la primera parte, a Ulpiano obnubilado por la grandeza de la capital espańola y totalmente atrapado por el furor sensual de una mujer que logra atraparlo en el matrimonio. Lo vemos deambular por los parques y las calles de Madrid, extrañando su pequeña ciudad, con el Selmer como único compañero de alma, que le permite llevar su bohemia a cuestas mientras da muestras de existencialismo y de nostalgia:

En Princesa (...) Coloqué el estuche en el suelo, lo abrí, armé las dos partes del instrumento con amor y empecé con "Love for sale". Tocaba con los ojos cerrados, inclinando el cuerpo hacia atrás y adelante como si no pudiera con el peso de un demonio o un dolor, con la vida pendiente del hilo de voz del saxo. Toqué luego "I got rhytm", "What is the thing called love", How is the moon? Sentí el poder del jazz en la sangre, su delirante libertad de ave de música, el cuchillo de nostalgia que atraviesa su belleza, su voluptuosidad al borde de un precipicio, su dolor hecho de sonidos del alma. Y fue mía la certeza cada vez más honda, de que la improvisación del jazz es la vida vivida sin nada extraño a ella, inclusive sin comida, la libertad que no tenemos en el corazón. Y la certeza de que esta música es pura fugacidad irrepetible, puro instante, puro amor sin dueńo o sin amada (Carrión, 2014, p. 84).

Vemos luego el hecho que constituye el nudo central de la obra, el rompimiento de la ilusión, cuando Ulpiano se entera de la mentira que provocará su deseo de regreso a la ciudad natal. Lo observamos huir, dejar sin explicación alguna a la mujer, y llegar a Loja, donde lo espera una familia adorada. Y al poco tiempo, vemos abrirse una puerta en la que aparece una mujer pintada como el mismo diablo, María Rosa, quien ha venido atrás de su esposo con el fin de quedarse a vivir con él en la pequeńa ciudad.

Aparece luego Ulpiano envuelto en una relación prohibida con su antigua novia Johana, hecho que va provocando el deseo de separación de su esposa, quien a 
estas alturas de la novela se ha convertido en una mujer descomunal parecida a un luchador de sumo. La falta de amor de estos dos personajes es evidente, así como lo es la necesidad de Ulpiano de acceder a su libertad, la cual parece imposible dada la amenaza de María Rosa de matarlo si descubre por parte de él alguna infidelidad. Es entonces cuando sobreviene la parte más intensa, dramática y de mayor suspenso de la novela: la invención de una serie de trampas a las que acude Ulpiano con el fin de matar a su mujer. Trata de electrocutarla, introduciendo un cable de luz en la bañera a la que entraría María Rosa, pero lo hace tan mal que termina fundiendo todos los equipos eléctricos de la casa. Intenta matarla, dejando abierta la llave del gas, pero este no va hacia el dormitorio de María Rosa, sino por el contrario se escapa por un conducto secreto del tumbado de la cocina y estalla la casa de la vecina. Por último, trata de matarla con un disparo en la hora más oscura de la noche, pero el arma explota en su rostro, mientras la risa siniestra de María Rosa se burla en mitad de la noche de algo que parece ser una ceguera. Este es un buen final, que muestra con humor corrosivo, como el odio ha dado paso a las más disparatadas invenciones para salirse con la suya.

A todo este argumento acompañan datos que hablan sobre la forma de ser bohemia del lojano. Ulpiano, un músico que ha formado un grupo de jazz denominado "Los Asesinos de Charlie Parker", que emprende varias giras, abandona la familia, el nuevo hijo nacido de María Rosa en tierras ecuatorianas, Telmo, a quien lleva ceniceros preciosos que roba en los hoteles y discotecas, y quien los arroja al piso, mientras María Rosa le reclama: "Chalado -qué no sabes que él no fuma”- (Carrión, 2014, p. 152). Y el perro, Argo, que le esconde las chancletas, se come el cuero de sus zapatos, se rasca las pulgas arracadas de su cuerpo para que caigan deliberadamente en su pantalón. Todos parecen confabular contra el personaje que lleno de amargura por una vida sin objetivo, se dedica a urdir la venganza. A todo este cuadro caricaturesco del machismo ecuatoriano, se suma la descripción del odio de María Rosa, quien se venga silenciosamente lesionando el Silver de Ulpiano, cada vez que este llega borracho y sin sentido a altas horas de la noche:

María Rosa lo ponía en mis manos, pero yo no lo reconocía. Estaba lleno de curitas, como otro borracho que hubiese tenido sus tres caídas dolorosas camino de su calvario. Aturdido, se las quitaba una por una, me lo llevaba a la boca para sacarle una nota, un acorde, y veía con horror los tropiezos de su voz y la espalda de María Rosa alejándose... (Carrión, 2014, p. 135).

Una muestra nada más, para decir que a pesar de los cuadros violentos que se pintan, estos no traducen una atmósfera que lacere el ojo del lector con estilo agresivo, más bien es la cualidad de lo lúdico instalada en las imágenes y formas de expresión, lo que otorga gracia a acontecimientos que de otro modo ofenderían.

Hablando de la estética del humor en las obras de Carrión analizadas en el presente ensayo, podemos concluir que se trata de un humor inquietante, que trans- 
forma nuestra realidad para hacernos conscientes de ella, de manera que en lugar de perdernos en la actitud de la queja, podamos ampliar la mirada hacia lo que resulta imprescindible recordar: nuestra gran capacidad de resiliencia. Otra cualidad que se suma al estilo humorístico de estas novelas es la ironía, que se conjetura a través de los varios actos narrados que dejan permear las debilidades de cada cultura, para mostrarnos como seres risibles frente actos de miserable humanidad. En este sentido, Carrión nos convierte en lectores reflexivos y nos ayuda a través de la risa a transformar la concepción que tenemos sobre nuestra colectividad, relativizándolo todo según el ojo que mira.

Si consideramos el concepto de humor negro como aquel que interpreta humorísticamente una realidad luctuosa, enfrentándonos con situaciones límites de la vida, las obras de Carrión analizadas aquí, calzan perfectamente con ese propósito de satirizar lo impensable. Las figuras literarias a las que acude el lector con este propósito son innumerables: anáforas, hipérboles, reiteraciones, antítesis, lenguaje popular, epítetos, dialogismos. De mano de estas figuras se busca racionalizar lo absurdo, abstraer saberes culturales, desenmascarar supersticiones, volvernos filosóficos.

Cuando se le pregunta a Carlos Carrión por qué escoge el tema del amor y el humor en sus obras, reflexiona:

Creo que los que escriben sobre el amor son los que no tienen amor, el escritor escribe sobre lo que no tiene, o sobre lo que ha perdido, al menos lo que no tiene a medida de sus deseos... Entonces, si yo escribo sobre el amor, supuestamente no tengo el amor que me llenaría para siempre, porque si fuera feliz el ser humano, no haría nada, estuviera engordando de felicidad. Yo, si fuera feliz, no me mataría escribiendo. Me enferma escribir; pero no puedo hacer otra cosa, es una esclavitud hermosa, hay esclavitudes buscadas como es el caso de la mía, y esclavitudes impuestas que son insoportables. El humor es una especie de gratificación para el lector, es el ingrediente que le hace falta a la vida, con un poco de humor se arregla todo. El amor y el humor se han mezclado en mis trabajos y creo que logran hacer sonreír y conmover. A mí mismo me favorece el humor que pongo en mis personajes, ellos tienen una vida alrededor de la cual yo me pongo de humor (cit in León, 2014, p. 101).

Entonces, más allá del fenómeno sociológico de la migración que engloba a estas tres obras, encontramos la invitación a interrogarnos, a definirnos, a respetarnos desde ángulos diferentes. Bienvenida sea la acogida que puedan tener sus obras, si en algo este estudio ha contribuido a difundirlas.

\section{Referencias}

Alarcón, S., Ordóńez, J., Torres, T. \& Contreras, M. (2010). Características socioeconómicas de los migrantes retornados a Loja (Ecuador). Loja: UTPL. Recuperado de http://blogs.upm.es/gedr/wp-content/uploads/sites/22/2014/06/Migrantes-Retornados-Loja.pdf 
Blasco Errans, I. (2015). Racismo y xenofobia en España (1975-2004). Recuperado de https://riull.ull.es/xmlui/bitstream/handle/915/3627/Racismo\%20y\%20 xenofobia\%20en\%20Espana\%20\%281975\%20a\%202004\%29.pdf?sequence $=1$ \&isAllowed $=y$

Carrasquilla, M. y Echeverri, M. (2002). Los procesos de integración social de los jóvenes ecuatorianos y colombianos en España: un juego identitario en los proyectos migratorios. Recuperado de http://www.injuve.es/sites/default/files/art5_Carrasquilla-Echeverri.pdf

Carrión, C. (2003). La utopia de Madrid. Quito: El Conejo. (2014). ¿Quién me ayuda a matar a mi mujer? Quito: EL Conejo (2014). La mantis religiosa. Quito: Libresa.

Herrera G., Carrillo M. \& Torres A. (2005). La migración ecuatoriana, transnacionalismo e identidades. Quito: Flacso.

Karageorgou-Bastea, C., Munguia, M. (2003). Luis Beltrán. La imaginación literaria. La seriedad y la risa en la literatura occidental. Acta Poética, 24. Obtenido de: https://revistas-filologicas.unam.mx/acta-poetica/index.php/ap/article/ view/159/158

Lada, F., Ulpiano y Cachero, A. (Eds.) (2010). Literatura y humor. Estudios téoricos críticos. España: Universidad de Oviedo.

León, G. (2014). Análisis y valoración de la obra de Carlos Carrión "El corazón es un animal en celo" a través de las figuras literarias. Zamora: UTPL.

Luna, A. (2013). Humor negro, una aproximación estética. Chile: Universidad de Chile. Recuperado de http://repositorio.uchile.cl/bitstream/handle/2250/112412/ Humor\%20Negro.pdf?sequence=1 \&isAllowed $=y$

Reyes Rojas, M. (2010). Reseña de "Psicología del humor: un enfoque integrador" de Martin, R. A. Revista Latinoamericana de Psicología, vol. 42, núm. 2, pp. 328334. Fundación Universitaria Konrad Lorenz. Bogotá, Colombia.

Salazar, G. (2013). La migración de lojanos a España y el sujeto migrante en La seducción de los sudacas. Loja: Universidad Nacional de Loja. Recuperado de C:/Users/ Ruth\%20Rodriguez/Downloads/264-13-447-1-10-20171017\%20(1).pdf 